\title{
Polycyclic and nitro musks in indoor air: a primary school classroom and a women's sport center
}

\begin{abstract}
Indoor air gas and particulate-phase samples $\left(\mathrm{PM}_{2.5}\right)$ were collected from a primary school classroom and a women's sport center because children are one of the sensitive population subgroups and women are frequent users of personal care products in addition to the high level of activity in this specific microenvironment. $\mathrm{PM}_{2.5}$ was collected with a Harvard impactor, and polyurethane foam was used for the gas phase. Samples were ultrasonically extracted, concentrated, and analyzed with a GC-MS. The mean gas-phase concentrations in the classroom ranged from $0.12 \pm 0.2 \mathrm{ng} / \mathrm{m}^{3}$ for MK to $267 \pm 56 \mathrm{ng} / \mathrm{m}^{3}$ for HHCB, while it was from $0.08 \pm 0.10 \mathrm{ng} / \mathrm{m}^{3}$ for AHMI to $144 \pm 61 \mathrm{ng} / \mathrm{m}^{3}$ for HHCB in the sports center. Particulate-phase average concentrations in the sports center ranged from $0.22 \pm 0.11 \mathrm{ng} / \mathrm{m}^{3}$ for ATII to $1.34 \pm 071 \mathrm{ng} / \mathrm{m}^{3}$ for AHTN, while it ranged from $0.05 \pm 0.02 \mathrm{ng} / \mathrm{m}^{3}$ (musk xylene) to $2.50 \pm 0.94$ $\mathrm{ng} / \mathrm{m}^{3}$ (HHCB) in the classroom. Exposure-risk assessment showed that inhalation route is most probably far less significant than the dermal route; however, it should be noted that the exposure duration covered in this study was not the larger fraction of the day.

\section{A. Sofuoglu ${ }^{1,2}$, N. Kiymet ${ }^{1}$, P. Kavcar', S. C. Sofuoglu ${ }^{1,2}$}

${ }^{1}$ Department of Chemical Engineering, Izmir Institute of Technology, Gülbahçe, Izmir, Turkey, ${ }^{2}$ Environmental Research Center, İzmir Institute of Technology, Gülbahçe, İzmir, Turkey

Key words: Synthetic musks; Indoor air; Gas phase; Particulate phase; Inhalation exposure; İmir.

A. Sofuoglu

Department of Chemical Engineering

İzmir Institute of Technology, Gülbahçe

Urla 35430 Izmir, Turkey

Tel.: +90 2327506650

Fax: +90 2327506645

e-mail: aysunsofuoglu@iyte.edu.tr

Received for review 11 February 2010. Accepted for publication 5 June 2010.
\end{abstract}

\section{Practical Implications}

Synthetic musk compounds (SMCs) are found everywhere because their use in household and personal care products (laundry detergents, carpet cleaners, cleaning agents, fabric softener soaps, shampoos, cosmetics, etc.) has been increasing. These compounds are semi-volatiles that may result in direct and indirect exposures through inhalation route. Although SMCs were found to be dominant in the gas phase, exposure via inhalable particles may be important as we found several compounds in the particulate phase $\left(\mathrm{PM}_{2.5}\right)$.

\section{Introduction}

Musks are organic compounds originally derived from animals or smell-emitting plants to use as fragrance in detergents, soaps, and other household and personal care products. The popularity of the musks as an ingredient in various products had resulted in the shortage of the natural supply, and the synthetic production of these compounds became inevitable. The worldwide production of synthetic musks shifted from nitro [musk xylene (MX), musk ketone (MK), musk moskene (MM), and musk tibettene (MT)] to polycyclic musks [tonalide (AHTN), galaxolide (HHCB), traseolide (ATII), celestolide (ADBI), phantolide (AHMI), and cashmeran (DPMI)] and increased in the amount of 1000 metric tons between the years 1987 and 1996 (Luckenbach and Epel, 2005) 
first time, they were found in human milk and adipose tissue (Rimkus and Wolf, 1996; Rimkus et al., 1994). Later, polycyclic musk fragrances were detected in water, fish, and some municipal sewage treatment plants (Rimkus et al., 1999). After the use of personal care products or cleaning agents, they are washed down to the drain and processed in treatment plants. Therefore, the major environmental contamination route for these compounds was through wastewater and treated wastewater discharges into receiving water bodies. Eventually, HHCB (31 ng/l) was detected in finished drinking water samples in the US (Benotti et al., 2009).

Samples from urban and rural areas were collected to investigate ambient air levels around the Great Lakes (Peck and Hornbuckle, 2006). They reported urban HHCB and AHTN levels of $1-5 \mathrm{ng} / \mathrm{m}^{3}$ and background terrestrial levels an order of magnitude less. Peters et al. (2008) studied many endocrine-disrupting chemicals including some polycyclic and nitro musks in the precipitation (rain) samples collected from 50 locations in the Netherlands. They detected nitro musks at a few locations, while they detected polycyclic musks in all samples. The use of polycyclic musks was common in Europe, while nitro musks were common in USA (Kallenborn et al., 1999).

SMC-containing products are frequently used indoors; indoor air is supposed to be the first and the most important environment for human exposure via inhalation. There are only a few studies that investigated indoor air levels of synthetic musks. The first study that investigated SMCs in indoor air confirmed their presence (Kallenborn and Gaterrmann, 2004). They found 'high' concentrations in indoor air gas samples in a hairdresser shop (average: $20 \mathrm{ng} / \mathrm{m}^{3}$; max: HHCB $44 \mathrm{ng} / \mathrm{m}^{3}$ ). Fromme et al. (2004) studied the occurrence of persistent environmental contaminants by taking indoor air samples from 59 apartments and 74 kindergartens in Berlin, Germany. They also collected house dust samples from 30 apartments. The median indoor air concentration in kindergartens was $101 \mathrm{ng} / \mathrm{m}^{3}$ for HHCB and $44 \mathrm{ng} / \mathrm{m}^{3}$ for AHTN, and maximum concentrations of up to 299 and $107 \mathrm{ng} /$ $\mathrm{m}^{3}$, respectively, were measured. HHCB and AHTN were detected in $63 \%$ and $83 \%$ of the house dust samples with median values of 0.7 and $0.9 \mathrm{mg} / \mathrm{kg}$, respectively. Chen et al. (2007) conducted an occupational determination of polycyclic musks in and around a cosmetics plant in China. Average total particulatephase concentration was considerably high even just outside the workshop $\left(6.4 \mathrm{ng} / \mathrm{m}^{3}\right)$ and at a downwind distance of $200 \mathrm{~m}$ away from the plant $\left(2.4 \mathrm{ng} / \mathrm{m}^{3}\right)$. Garcia-Jares et al. (2009) reviewed performance of the analytical techniques used for semi-volatiles in terms of sample collection, pretreatment, extraction, clean-up, and determination. Reguerio et al. (2009) proposed a new analytical methodology for the analysis of SMCs by combining solid-phase extraction and solid-phase microextraction. The method was applied successfully in indoor air of homes in North-western Spain. Measured concentrations of HHCB and AHTN were in the range from 143 to $1129 \mathrm{ng} / \mathrm{m}^{3}$ and from 21 to $77 \mathrm{ng} / \mathrm{m}^{3}$, respectively. ADBI and AHMI were found only in one sample, while DPMI, ATII, and MM were not detected in any of the samples.

In summary, the results of all studies suggest widespread occurrence of synthetic musks in different environmental compartments. Kannan et al. (2005) recently determined HHCB and AHTN levels in both human adipose fat collected from New York City and wildlife animals (marine mammals, water birds, and fish) collected from the US waters. They concluded that further studies should be conducted to evaluate and characterize exposures and toxicity of these compounds on humans and wildlife. These compounds are considered as xenobiotics (Kallenborn and Gaterrmann, 2004) and have been found to disrupt the endocrine system by exerting weak estrogenic or other hormonal activity (Bitsch et al., 2002; Burg et al., 2008).

Environmental risk assessments were conducted for MK and MX (Tas et al., 1997) and for AHTN and HHCB (Balk and Ford, 1999). The risk levels for all four compounds were found to be low for aquatic and sediment organisms, whereas the levels for soil organisms were deemed as a call upon further research for MK and especially for MX. An exposure-based risk assessment for hypothetical products (a leave-on eau de toilette and a rinse-off shampoo) containing $1000 \mathrm{ppm}$ or more cinnamic aldehyde (Gerberick et al., 2001) estimated that induction of skin sensitization risk was unacceptable for the leave-on product, while the risk posed by the rinse-off product was deemed acceptable. The systemic exposures to AHTN and HHCB were determined in rats under occlusion and in humans under simulated conditions of dermal exposure (Ford et al., 1999). The animal study showed that the total amount absorbed was approximately $19 \%$ for AHTN and $14 \%$ for HHCB, whereas the human study conducted with the help of three male volunteers showed that the total absorbed dose was approximately $1 \%$ and $0.1 \%$ for AHTN and $\mathrm{HHCB}$, respectively, based on excretion. The authors reported that about $20 \%$ of the applied amount on average was shown to evaporate under the conditions of exposure.

Even though the major route of exposure to synthetic musk compounds, dermal absorption, has been studied extensively, there is a lack of information about exposure by inhalation, especially indoors. In addition, gas-particulate phase distribution has not been investigated. Therefore, the main objective of this study was set as the determination of the short-term gas and particulate phase $\left(\mathrm{PM}_{2.5}\right)$ synthetic musk compound concentrations and phase distribution in 
two different indoor microenvironments where significant human exposure may occur: a primary school classroom and a women's sports center.

\section{Materials and methods}

Chemicals and materials

1,2,3,5,6,7-Hexahydro-1,1,2,3,3-pentamethyl-4H-inden4-one (Cashmeran, DPMI), 4-acetyl-1,1-dimethyl-6tertbutylindan (Celestolide, ADBI), 6-acetyl- 1,1,2,3,3, 5-hexamethylindan (Phantolide, AHMI), 5-acetyl1,1,2,6-tetramethyl-3-iso-propylindan (Traseolide, ATII), 7-acetyl-1,1,3,4,4,6-hexamethyl-1,2,3,4-tetrahydronaphthalene (Tonalide, AHTN), and 1,3,4,6,7,8-hexahydro-4,6,6,7,8,8-hexamethylcyclopenta(g)-2-benzopyrane (Galaxolide, HHCB), Musk Ketone (MK) and MX were purchased from LGC Prochem (Teddington, UK), while flourantene- $\mathrm{d}_{10}$ from Dr.Ehrenstorfer GmbH (Augsburg, Germany). Gas chromatographic grade of ethyl acetate, acetone, and $n$-hexane (Suprasolv; Merck, Darmstadt, Germany) was used for the extraction and column chromatography applications. Ultrapure chemical-free MilliQ (Millipore Elix-5) water was used in all steps of the analytical procedure.

Florisil (100-200 mesh; Sigma-Aldrich, St. Louis, MO, USA), a magnesium silicate with basic properties, has been used for the clean-up of pesticide residues, polychlorinated biphenyls (PCBs), polyaromatic hydrocarbons (PAHs), chlorinated hydrocarbons, aromatic compounds, fat, oil, waxes, and separation of nitrogen compounds from hydrocarbons (USEPA, 2007). Florisil was activated at $650^{\circ} \mathrm{C}$ overnight. Then, it was cooled and stored in a desiccator at room temperature. For the deactivation of florisil, $37.5 \mu \mathrm{l}$ of water was added for each $0.75 \mathrm{~g}$ of florisil before filling up the clean-up and enhancement column to remove impurities and enhance the SMCs in the sample matrix. The column was topped with $1 \mathrm{~cm}$ of the anhydrous sodium sulfate (Fluka, Steinheim, Germany), which was baked at $450^{\circ} \mathrm{C}$ overnight.

Polyurethane foam (PUF) cartridges were cleaned by Soxhlet extraction using dichloromethane (Pestanal, Riedel-de Haen, Seelze, Germany) for $6 \mathrm{~h}$ followed by a mixture of acetone and $n$-hexane (1:1) for $8 \mathrm{~h}$. After extraction, PUFs were wrapped loosely with aluminum foil and dried at $60^{\circ} \mathrm{C}$ for $3 \mathrm{~h}$ in an oven. They were kept in glass jars with teflon-lined lids until use. Glass fiber filters (GFF) (Pall, Type A/E, Ø $37 \mathrm{~mm}$, pores $1 \mu \mathrm{m})$ were wrapped loosely with aluminum foil and baked overnight at $450^{\circ} \mathrm{C}$. Then, they were cooled and stored in desiccators until use (Kiymet, 2009).

Sampling

Samples were collected between June 16 and July 6, 2009 , in a sports center where approximately 50 women aged 18-60 visit daily, and between November 4 and 21,2008 , in a classroom of 30 children aged seven in a primary school where approximately 1750 students attend, in İzmir, Turkey. Ten daytime gas and $\mathrm{PM}_{2.5}$ particulate-phase samples were collected for $8 \mathrm{~h}$ with a $101 /$ min flow rate in each of the two microenvironments on PUF and GFFs, respectively, with an active sampling system consisted of a Harvard impactor and a pump (Air Diagnostics \& Engineering Inc., Harrison, ME, USA). The impactor consisted of (i) the sampling inlet, (ii) the particle impactor with $2.5-\mu \mathrm{m}$-size cut, and (iii) the filter holder. The impactor was connected to a hollow cylinder that held a PUF cartridge $(\varnothing$ $22 \mathrm{~mm}, 100 \mathrm{~mm}$ length; SKC, Dorset, UK) placed in a glass cylinder (SKC) where gas-phase compounds were collected. The sampling train was connected to the pump (Air Diagnostics \& Engineering Inc., SP-280). Sample volumes were approximately $4.8 \mathrm{~m}^{3}$ air. The pump was calibrated using a flow meter (Defender 510$\mathrm{H}$; BIOS, Buttler, NJ, USA) prior to sampling. At the end of sampling, the flow rate was measured for the calculation of daily average flow rate and to verify whether the difference was within $10 \%$ to deem the sample acceptable.

\section{Sample extraction and clean-up}

The extraction method used in this study was adapted from Peck and Hornbuckle (2006). Prior to extraction, $10 \mu \mathrm{l}$ of fluoranthene- $d_{10}$ surrogate standard solution (50 $\mathrm{pg} / \mu \mathrm{l}$ concentration) was added to each of particulate and gas-phase samples. Then, the samples were ultrasonically extracted in 40-ml amber vials, containing $20 \mathrm{ml}$ acetone and $20 \mathrm{ml} n$-hexane for $1 \mathrm{~h}$, followed by evaporation and concentration procedure with nitrogen down to $2 \mathrm{ml}$ in volume. Each extract was passed through a column filled with florisil. Then, $4 \mathrm{ml}$ ethyl acetate was passed through the column, and the eluate was collected in an amber vial. Sample extracts were concentrated down to $1 \mathrm{ml}$ after the change of solvent into $n$-hexane. Samples were placed into a freezer until analysis.

\section{GC/MS analysis}

A gas chromatograph (Thermo, Trace GC Ultra, Austin, TX, USA) coupled to a mass selective detector (Thermo DSQII) with electron impact ionization $(\mathrm{GC} /$ EI-MS) operated in selective ion monitoring (SIM) mode was used for the analysis of eight synthetic musk compounds. A 30-m 5\% phenyl methyl siloxane capillary column (HP-5MS; $250 \mu \mathrm{m}$ I.D., $0.25 \mu \mathrm{m}$ film thickness) was used. Samples were injected via programmable temperature vaporizer (PTV) port in splitless mode with a splitless time of $1 \mathrm{~min}$. A constant $1 \mathrm{ml} / \mathrm{min}$ column flow rate was used for the carrier gas of helium. The oven temperature was held at $60^{\circ} \mathrm{C}$ for 
Table 1 Retention time and ions of synthetic musk compounds

\begin{tabular}{lcll}
\hline Compound & Retention time $(\mathrm{min})$ & Target ion & Qualifier ion $(\mathrm{m} / \mathrm{z})$ \\
\hline DPMI & 9.51 & 191 & 206 \\
ADBI & 12.15 & 229 & 244 \\
AHMI & 12.92 & 229 & 244 \\
ATII & 14.88 & 215 & 258 \\
HHCB & 14.97 & 243 & 213 \\
MX & 15.21 & 282 & 292 \\
AHTN & 15.27 & 243 & 258 \\
MK & 19.07 & 279 & 294 \\
Flouranthene- $\mathrm{d}_{10}$ & 21.77 & 212 & \\
\hline
\end{tabular}

$1 \mathrm{~min}$. Then, temperature was ramped from 60 to $180^{\circ} \mathrm{C}$ at $15^{\circ} \mathrm{C} / \mathrm{min}$ followed by a $0.2^{\circ} \mathrm{C} / \mathrm{min} \mathrm{ramp}$ to $185^{\circ} \mathrm{C}$. The final temperature $\left(290^{\circ} \mathrm{C}\right)$ was held for $6 \mathrm{~min}$. It is recommended that the slow temperature gradients are necessary for the simultaneous analysis of the SMCs (Peck and Hornbuckle, 2006). The MS transfer line temperature was $300^{\circ} \mathrm{C}$. Compounds were identified on the basis of their retention times, target, and qualifier ions and were quantified using the internal standard calibration procedure (Table 1).

\section{Quality assurance and quality control}

The glassware and metal parts of the impactor were washed with Alconox detergent (fragrance free, White Plains, NY, USA), solvent-rinsed, covered with aluminum foils, dried in an oven $\left(4 \mathrm{~h}\right.$ at $110^{\circ} \mathrm{C}$ for glassware and $3 \mathrm{~h}$ at $60^{\circ} \mathrm{C}$ for metal parts), and kept there until use. In addition to this procedure, to minimize the contamination from soap, hand creams, and perfumes, nobody in the laboratory used personal care products during the sampling and analytical procedure. Blank PUF cartridges and GFFs $(n=3)$ were placed in the field to determine whether there was any contamination during sample handling and preparation. The field blanks were carried to the sampling site in teflon-lined glass jars in sealed plastic bags in an ice box and then placed into the sampling train with no air drawing through. Background contamination was checked by laboratory blank samples $(n=4)$. The number of detected synthetic musks was higher in laboratory blanks than in field blanks. DPMI, ATII, HHCB, and ATHN were detected in laboratory blanks, while only ATII, HHCB, and ATHN were detected in the field blanks, at similar levels. Samples were laboratoryblank-corrected. Limit of detection (LOD) values were calculated from a signal-to-noise ratio of $3 / 1$.

All samples were corrected for method recovery according to internal standard method using fluoranthene- $\mathrm{d}_{10}$ as the surrogate standard. However, Chen et al. (2007) stated that there was no ideal surrogate standard for the analysis of SMCs. Therefore, spike recovery samples $(n=3$ for GFFs and $n=4$ for PUFs) were run for the calculation of external recoveries to confirm the results obtained by the use of
Table 2 Percent retained in the front plug (the sample)

\begin{tabular}{lcc}
\hline Compounds & The classroom $(\%)$ & The sports center (\%) \\
\hline DPMI & $48.6 \pm 5.70$ & $49.3 \pm 10.5$ \\
ADBI & $86.2 \pm 5.22$ & $79.8 \pm 5.11$ \\
AHMI & - & - \\
ATII & $92.6 \pm 1.89$ & $76.9 \pm 6.14$ \\
HHCB & $92.2 \pm 1.60$ & $76.6 \pm 5.98$ \\
MX & $96.7 \pm 1.86$ & $88.6 \pm 4.40$ \\
AHTN & $95.2 \pm 1.71$ & $84.0 \pm 5.39$ \\
MK & - & - \\
\hline
\end{tabular}

surrogate standard. The recovery values for the gas phase (PUF) were lower than those for the particulate phase but acceptable. The mean recoveries for the gas phase ranged from $44 \%$ (DPMI) to $54 \%$ (MK), while they were between $69 \%$ (DPMI) and $85 \%$ (MK) for the particulate-phase media, which were similar to those obtained by the use of surrogate standard.

Determination of the breakthrough or volatilization from gas phase was achieved by analyzing four backup samples taken in each sampling microenvironment. The back-up plug was serially connected to the sample (front plug). Both of the plugs were individually extracted and analyzed. The analytes found in the back-up plug were compared with the front plug. Portions captured in each plug were calculated as percent of the total amount for each analyte. The results showed that retention percentage in the front plug (real sample) varies from compound to compound (Table 2). The differences in the retention percentages among the musk compounds may be attributable to the differences in their vapor pressures. DPMI has the highest vapor pressure $(5.2 \mathrm{~Pa})$, while $\mathrm{MX}$ has the lowest $(0.00003 \mathrm{~Pa})$. Vapor pressure is also a temperature-dependent property (Paasivirta et al., 2002); therefore, seasonal differences were also thought to have an effect on the retained amounts. Time of sampling was November for the classroom, while it was July for the sports center. As a result, to make sure no or little breakthrough occurs at relatively higher temperatures, care should be taken by using a lower sampling volume, using solid-phase sampling media with PUF (sandwiched between halves of a PUF cartridge), or using a combination of solid-phase extraction and solid-phase microextraction as suggested by Reguerio et al. (2009).

\section{Results and discussion}

Particulate-phase concentrations

Indoor air particulate-phase $\left(\mathrm{PM}_{2.5}\right)$ SMC concentrations were measured in the primary school classroom and the women's sports center. In the classroom, five of eight musk compounds (ADBI, ATII, HHCB, MX, and AHTN) were detected with frequencies ranging 
Table 3 Detection frequencies and the mean concentrations ( \pm standard deviation)

\begin{tabular}{|c|c|c|c|c|c|c|c|c|}
\hline \multirow[b]{2}{*}{ SMC } & \multicolumn{4}{|c|}{ Primary school classroom } & \multicolumn{4}{|c|}{ Women's sport center } \\
\hline & Gas phase* & Frequency (\%) & Particulate phase* & Frequency $(\%)$ & Gas phase* & Frequency (\%) & Particulate phase* & Frequency $(\%)$ \\
\hline DPMI & $84.5 \pm 35.2$ & 100 & nd & - & $16.90 \pm 6.7$ & 100 & nd & - \\
\hline ADBI & $1.45 \pm 0.28$ & 100 & $0.02 \pm 0.01$ & 100 & $1.01 \pm 0.37$ & 100 & nd & - \\
\hline AHMI & $0.18 \pm 0.13$ & 70 & nd & - & $0.08 \pm 0.06$ & 70 & nd & - \\
\hline ATII & $58.7 \pm 12.5$ & 100 & $0.58 \pm 0.20$ & 100 & $31.0 \pm 13.1$ & 100 & $0.22 \pm 0.11$ & 100 \\
\hline НССВ & $267.3 \pm 56.0$ & 100 & $2.50 \pm 0.94$ & 100 & $144.0 \pm 60.5$ & 100 & $0.94 \pm 0.52$ & 100 \\
\hline MX & $9.89 \pm 2.76$ & 100 & $0.05 \pm 0.02$ & 90 & $3.24 \pm 2.26$ & 100 & nd & - \\
\hline AHTN & $59.6 \pm 13.5$ & 100 & $1.19 \pm 0.37$ & 100 & $39.5 \pm 14.7$ & 100 & $1.34 \pm 0.71$ & 100 \\
\hline MK & $0.12 \pm 0.16$ & 40 & nd & - & nd & - & nd & - \\
\hline
\end{tabular}

${ }^{*}$ All concentrations in $\mathrm{ng} / \mathrm{m}^{3}$, nd, not detected.
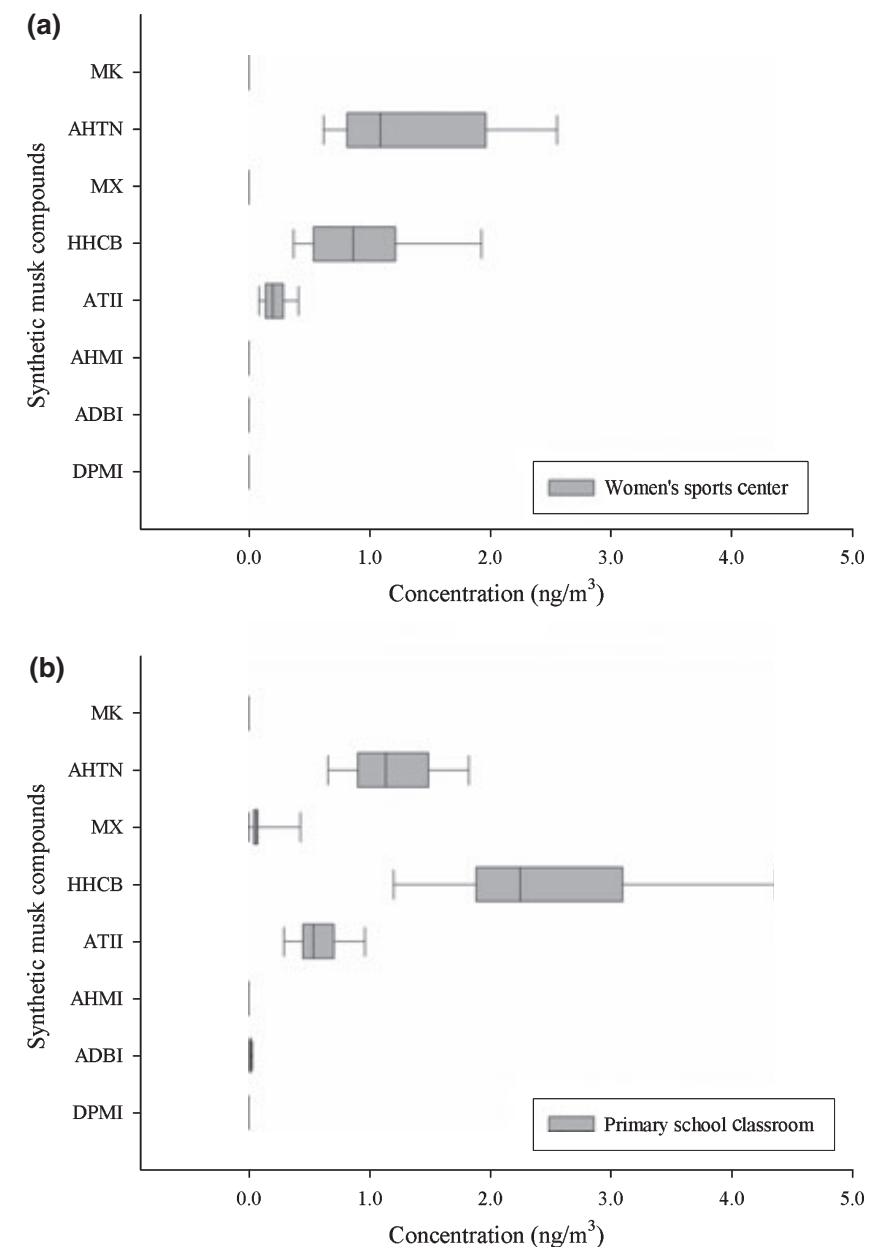

Fig. 1 The Particulate-phase concentrations (a) primary school classroom, (b) women's sports center

from $40 \%$ to $100 \%$ (Table 3 ). The highest concentrations were determined for HHCB and AHTN, while the lowest concentrations were found for ADBI, followed by ATII and MX (Figure 1b). In the sports center, only three musk compounds (HHCB, ATII, and AHTN) were detected (Figure 1a). Average concentrations in the sports center ranged from $0.22 \mathrm{ng} / \mathrm{m}^{3}$ for ATII to $1.34 \mathrm{ng} / \mathrm{m}^{3}$ for AHTN, while it ranged from $0.05 \mathrm{ng} / \mathrm{m}^{3}$ (MX) to $2.50 \mathrm{ng} / \mathrm{m}^{3}$ (HHCB) in the classroom (see Table 3 ).

Indoor air particulate-phase SMC concentrations were measured only in a cosmetics plant in China (Chen et al., 2007). The total particulate-phase musk concentration was reported as $127 \pm 41 \mathrm{ng} / \mathrm{m}^{3}$ in a workshop of the plant. The concentrations dropped to $6.39 \pm 1.35 \mathrm{ng} / \mathrm{m}^{3}$ just outside the workshop and to $2.35 \pm 0.25 \mathrm{ng} / \mathrm{m}^{3} 200 \mathrm{~m}$ away downwind. The contribution of particulate phase to the total concentration increased with distance away from the plant. As it may be expected, the occupational indoor air concentrations were much higher than the concentrations measured in this study.

Gas-phase concentrations

Average gas-phase concentrations in the classroom ranged from $0.12 \mathrm{ng} / \mathrm{m}^{3}$ for $\mathrm{MK}$ to $267 \mathrm{ng} / \mathrm{m}^{3}$ for HHCB, while they varied from $0.08 \mathrm{ng} / \mathrm{m}^{3}$ for AHMI to $144 \mathrm{ng} / \mathrm{m}^{3}$ for HHCB in the sports center (Table 3). The order of the SMCs from the highest to the lowest concentration was HHCB $>$ DPMI $>$ AHTN $>$ ATII $>$ MX $>$ ADBI $>$ AHMI $>$ MK in the classroom, whereas a different order was observed as $\mathrm{HHCB}>\mathrm{AHTN}>\mathrm{ATII}>\mathrm{DPMI}>\mathrm{MX}>\mathrm{ADBI}$ $>$ AHMI in the sports center. Musk ketone was not detected in the sports center at all. The dominant compound was HHCB in both of the microenvironments.

Fromme et al. (2004) studied gas-phase SMC concentrations in apartments and kindergartens in Berlin. Among the 74 measurements in kindergartens, HHCB had the highest concentrations with an average of $101 \mathrm{ng} / \mathrm{m}^{3}$ (range: $15-299 \mathrm{ng} / \mathrm{m}^{3}$ ), similar to those measured in this study. HHCB made the greatest contribution $(61 \%)$ to the total concentration in kindergartens, which was followed by AHTN $(26 \%)$ and AHMI $(12 \%)$. DPMI and MX were not determined in any of the samples, while MK and ATII were found in a few samples at levels from $12 \mathrm{ng} / \mathrm{m}^{3}$ to a 
maximum of $17 \mathrm{ng} / \mathrm{m}^{3}$. Chen et al. (2007) also measured the gas-phase concentrations of polycyclic musks (DPMI, ADBI, AHMI, ATII, AHTN, and HHCB) in the air of a cosmetics plant. The total concentration in the plant was $5416 \pm 1079 \mathrm{ng} / \mathrm{m}^{3}$, and $96.5 \%$ of contribution was coming from HHCB and AHTN, the two highest concentration compounds. These concentrations are much greater than those measured in this study. Chen et al. (2007) also measured the concentrations around the plant and stated that the levels were sufficiently high to affect habitants around the plant.

The most frequently detected compounds in our study are similar to those reported in the literature except for DPMI. This may be because of the common use of these compounds in household and personal care products. In general, DPMI was rarely detected among other SMCs (Peck and Hornbuckle, 2004; Ricking et al., 2003). In contrast, Peters (2003) studied 36 brands of perfume to determine the SMCs content and reported that DPMI was detected in 16 out of 36 brands. In addition, Peters et al. (2008) detected DPMI in a study of xenobiotic compounds in the precipitation.

The classroom gas-phase concentrations were higher than those at the sports center (Figure 2). The gasphase concentrations measured in the classroom (ranged from $0.12 \mathrm{ng} / \mathrm{m}^{3}$ for MK to $267 \mathrm{ng} / \mathrm{m}^{3}$ for HHCB) were similar to the mean concentrations ranging between 22 and $119 \mathrm{ng} / \mathrm{m}^{3}$ (with a maximum concentration of $299 \mathrm{ng} / \mathrm{m}^{3}$ for HHCB) reported by Fromme et al. (2004) for Berlin kindergartens. The difference observed between the classroom and the sports center may be attributable to the higher population density in the classroom as the number of clothes washed with scented products may be a strong source assuming children do not use pertinent personal care products. In addition, according to our experience, the schools prefer scented cleaning products. Moreover, differences in the strength of cleaning products, cleaning durations, the level of natural ventilation, and the time (season) of the sampling may have caused the differences in the concentrations. It was observed that a natural soap was used in the sports center for cleaning, which makes the personal care products worn by the attending and working women and the room freshener as the sole sources of SMCs. Because both microenvironments were naturally ventilated, varying air exchange rates occur during the day as windows were opened depending on the occupants' desire, which causes fluctuations in instantaneous concentrations and exposures. As a result, higher exposures than the 8-h average concentration could occur in the sports center for women who exercise during low ventilation conditions but not likely in the classroom because children are present in the most of the 8 -h period.
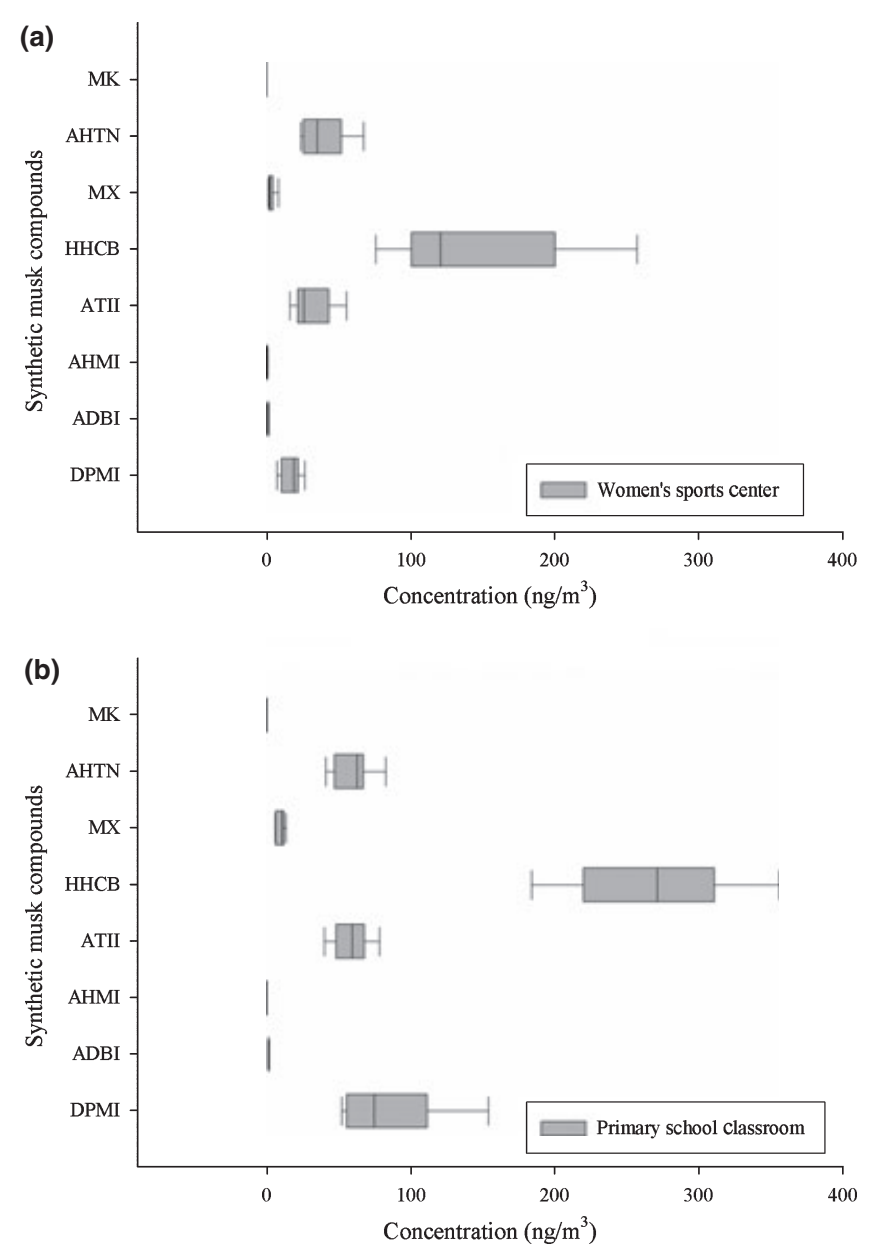

Fig. 2 The gas-phase concentrations (a) primary school classroom, (b) women's sports center

Distribution of SMCs between gas and particulate phases showed that all the SMCs were dominant in the gas phase $(>96 \%$ in the sports center and $>98 \%$ in the classroom). Only HHCB, AHTN, and ATII were determined in the particulate phase as all the others were $100 \%$ in the gas phase in the sports center. On the other hand, the number of compounds detected in the particulate-phase samples was higher (ADBI, AHTN, ATII, HHCB, and MX) in the classroom.

\section{Human health risk assessment}

The Scientific Committee on Cosmetic and Non-Food Products (SCCNFP) of European Union has conducted a human health risk assessment for dermal exposure to synthetic musk compounds using industryprovided cosmetic product frequency of use data and toxicological data reported by Lehman-Mckeeman et al. (1997), which characterized the profile and dose-response relationship of microsomal enzyme induction owing to exposure to MX (SCCNFP, 2004). Assuming a no observed adverse effect level (NOAEL) of $10 \mathrm{mg} / \mathrm{kg}$ per day and $10 \%$ absorption 
(Abs) for the estimated average daily dose (ADD) of $224 \mu \mathrm{g} / \mathrm{kg}$ per day, margin of safety (MOS) was calculated as 455 . On the basis of the T25 method, lifetime cancer risk of $3 \times 10^{-4}$ was calculated for the above-mentioned daily dose. In other words, the human equivalent dose of $7.3 \mu \mathrm{g} / \mathrm{kg}$ per day corresponds to a carcinogenic risk level of $1 \times 10^{-4}$. Risk levels for musk ketone were also calculated, however, based on the toxicological data produced for MX, i.e., NOAEL $=10 \mathrm{mg} / \mathrm{kg}$ per day and the human equivalent dose of $7.3 \mu \mathrm{g} / \mathrm{kg}$ per day that corresponds to a carcinogenic risk level of $1 \times 10^{-4}$. Based on the estimated exposure dose of $218 \mu \mathrm{g} / \mathrm{kg}$ per day and $14 \%$ absorption, MOS and lifetime carcinogenic risk were calculated as 333 and $4 \times 10^{-4}$, respectively. The opinion of the committee for both of the compounds was 'Taken into consideration that only one animal carcinogenicity study in one species is available, that it is likely that the tumors are induced by a nongenotoxic mechanism and that a threshold may be present, the calculated risk is considered tolerable.' In an inhalation exposure study (Fukayama et al., 1999), rats or hamsters (whole body) were exposed to a fragrance mixture at 5,9 or $50 \mathrm{mg} / \mathrm{m}^{3}$ for $4 \mathrm{~h}$ per day, 5 days per week for 6 or 13 weeks, which represented a 10-100-fold exaggeration of levels expected to occur during typical use by consumers. The mixture contained $\mathrm{HHCB}$ and MK among other 68 ingredients at a level of $1 \%$ or more. The highest level of the two compounds in different experiments was 132 and $171 \mu \mathrm{g} / 1$, respectively. The subchronic exposure did not result in any significant toxicological effect, so the authors concluded that the fragrance mixture would not pose a hazard to the consumers.

The SCCNFP approach was taken as guidance for the risk assessment of MX and MK in this study. In calculation of risk levels in the sport center and the primary school, $100 \%$ absorption for inhalation exposure route and heavy activity were assumed as a conservative scenario. Recommended short-term heavy activity breathing rate is 3.2 and $1.9 \mathrm{~m}^{3} / \mathrm{h}$ for adults and children, respectively (USEPA, 1997). The resulting doses were calculated for adults in the sports center and the children in the school, based on exposure durations of 1 and $8 \mathrm{~h} /$ day, respectively. Average body weight was taken as $60 \mathrm{~kg}$ for adult women and $26 \mathrm{~kg}$ for children aged 7-8 (USEPA, 1997). Average daily dose (ADD) was estimated using Equation 1, whereas Margin of Exposure (MOE), which is analogous to MOS, was calculated using Equation 2. The lifetime carcinogenic risk estimates were calculated based on the reported lifetime cancer risk of $1.0 \times 10^{-4}$ at $7.3 \mu \mathrm{g} /$ $\mathrm{kg}$ per day (Equation 3).

$$
\begin{aligned}
\mathrm{ADD} & =(C \times \mathrm{IR} \times \mathrm{ED} \times \mathrm{Abs}) / \mathrm{BW} \\
\mathrm{MOE} & =\mathrm{NOAEL} / \mathrm{ADD} \\
R & =\mathrm{ADD} \times 1.0 \times 10^{-4} / 7.3 .
\end{aligned}
$$

where ADD is the upper bound estimate of average daily dose $(\mu \mathrm{g} / \mathrm{kg}$ per day); $C$ is the maximum contaminant concentration in air $\left(\mu \mathrm{g} / \mathrm{m}^{3}\right)$; IR is inhalation rate $\left(\mathrm{m}^{3} / \mathrm{h}\right)$; ED is exposure duration (h/day); Abs is absorption ratio (unitless); BW is body weight $(\mathrm{kg}) ; R$ is lifetime carcinogenic risk; and 7.3 is the dose $(\mu \mathrm{g} / \mathrm{kg}$ per day) that corresponds to the risk level of $1.0 \times 10^{-4}$. The maximum value for concentration was taken as an upper bound estimate. The estimated risk levels are presented in Table 4. The levels indicate that the risk estimates are low (well below the general acceptable risk levels) and in agreement with the risks in the literature cited earlier. The estimated inhalation route exposure doses are much lower than those estimated by the Committee (SCCNFP, 2004) for dermal absorption route. However, it should be noted that the estimated exposure doses in this study cover a smaller part of the day in which majority of time is spent at home. Therefore, one needs to draw conclusions regarding the apportionment of the exposures via dermal and inhalation routes after having knowledge on the SMC concentrations in residential indoor air. We also should note that all estimated human health risk levels in this study and the dermal route study (SCCNFP, 2004) are broad estimations with high levels of uncertainty because of the fact that employed risk factors were based on only one study conducted with one species and population variation in exposure factors were not considered by employing point estimates.

\section{Conclusion}

Indoor air gas and particulate-phase concentrations of polycyclic and nitro musks were measured in a primary school classroom and a women's sports center. Although the majority were found in the gas phase $(>95 \%)$, synthetic musk compounds were also detected in the particulate phase $\left(\mathrm{PM}_{2.5}\right)$. The concentrations were higher in the classroom compared to the sports center. Exposure-risk assessment showed that inhalation route is most probably far less significant than the dermal route; however, because the exposure duration covered in this study was not the larger fraction of the day, further investigation is needed and planned. Even though the particulate-phase concentrations were low compared to gas phase, these may

\begin{tabular}{|c|c|c|c|c|c|c|}
\hline \multirow{2}{*}{$\begin{array}{l}\text { Musk } \\
\text { compound }\end{array}$} & \multicolumn{3}{|c|}{ Primary school } & \multicolumn{3}{|c|}{ Women's sport center } \\
\hline & ADD & MOE & $\mathrm{R}$ & ADD & MOE & $\mathrm{R}$ \\
\hline MX & $8.1 \times 10^{-3}$ & $1.2 \times 10^{6}$ & $1.1 \times 10^{-7}$ & $4.5 \times 10^{-4}$ & $2.2 \times 10^{7}$ & $6.2 \times 10^{-9}$ \\
\hline MK & $2.1 \times 10^{-4}$ & $4.8 \times 10^{7}$ & $2.8 \times 10^{-9}$ & NA & NA & NA \\
\hline
\end{tabular}
still pose a significant risk, given that the musk

Table 4 Estimated risk levels for musk xylene (MX) and musk ketone (MK)

$N A$, not available due to below detection limit concentrations; ADD, average daily dose $(\mu \mathrm{g} / \mathrm{kg}$ per day); $\mathrm{MOE}$, margin of exposure; $\mathrm{R}$, carcinogenic risk. 
compounds would be available for absorption for longer periods of time, while particles that hold the musk and other semi-volatile compounds such as PCBs, polybrominated diphenyl ethers, phthalates, etc. sit after settling down on the surfaces of the respiratory system.

\section{Acknowledgement}

This study was supported by a research grant (105Y263) from the Scientific and Technical Research Council of Turkey (TUBITAK).

\section{References}

Balk, F. and Ford, R.A. (1999) Environmental risk assessment for the polycyclic musks, AHTN and HHCB II. Effect assessment and risk characterisation, Toxicol. Lett., 111, 81-94.

Bektasoglu, S. and Bektas, B. (2008) Cleaning Products, A report to Undersecretariat of the Prime Ministry for Foreign Trade, Ankara, Turkey (in Turkish).

Benotti, M.J., Trenholm, R.A., Vanderford, B.J., Holady, J.C., Stanford, B.D. and Snyder, S.A. (2009) Pharmaceuticals and endocrine disrupting compounds in U.S. drinking water, Environ. Sci. Technol., 43, 597-603.

Bitsch, N., Dudas, C., Körner, W., Failing, K., Biselli, S., Rimkus, G. and Brunn, H (2002) Estrogenic activity of musk fragrances detected by the E-screen Assay using human MCF-7 cells, Arch. Environ. Contam. Toxicol., 43, 257-264.

Burg, B., Schreurs, R., Linden, S., Seinen, W., Brouwer, A. and Sonneveld, E. (2008) Endocrine effects of polycyclic musks: do we smell a rat? Int. J. Androl., 31, 188-193.

Chen, D., Zeng, X., Sheng, Y., Bi, X., Gui, H., Sheng, G. and Fu, J. (2007) The concentrations and distribution of polycyclic musks in a typical cosmetic plant, Chemosphere, 66, 252-258.

Ford, R.A., Hawkins, D.R., Schwarzenbach, R. and Api, A.M. (1999) The systemic exposure to the polycyclic musks, AHTN and HHCB, under conditions of use as fragrance ingredients: evidence of lack of complete absorption from a skin reservoir, Toxicol. Lett., 111, 133-142.

Fromme, H., Lahrz, T., Piloty, M., Gebhart, H., Oddoy, A. and Jüden, H. (2004) Occurrence of phthalates and musk fragrances in indoor air and dust from apartments and kindergartens in Berlin (Germany), Indoor Air, 14, 188-195.

Fukayama, M.Y., Easterday, O.D., Serafino, P.A., Renskers, K.J., North-Root, H. and Schrankel, K.R. (1999) Subchronic inhalation studies of complex fragrance mixtures in rats and hamsters, Toxicol. Lett., 111, 175-187.

Garcia-Jares, C., Regueiro, J., Barro, R., Dagnac, T. and Llompart, M. (2009) Analysis of industrial contaminants in indoor air. Part 2. Emergent contaminants and pesticides, J. Chromatogr. A, 1216, 567-597.
Gerberick, F.G., Robinson, M.K., Felter, S.P., White, I.A. and Basketter, D.A. (2001) Understanding fragrance allergy using an exposure-based risk assessment approach, Contact Derm., 45, 333-340.

Kallenborn, R. and Gaterrmann, R. (2004) Synthetic musks in ambient and indoor air. In: The Handbook of Environmental Chemistry, Vol. 3, 85-104.

Kallenborn, R., Gatermann, R., Planting, S., Rimkus, G.G., Lund, M., Schlabach, M. and Burkow, I.C. (1999) Gas chromatographic determination of synthetic musk compounds in Norwegian air samples, $J$. Chromatogr. A, 846, 295-306.

Kannan, K., . Reiner, J.L., Yun, S.H., Perrotta, E.E., Tao, L., Johnson-Restrepo, B. and Rodan, B.D. (2005) Polycyclic musk compounds in higher trophic level aquatic organisms and humans from the United States, Chemosphere, 61, 693-700.

Kiymet, N. (2009), Determination of Synthetic Musk Compound Levels in Indoor Air, MSc Thesis, Izmir Institute of Technology.

Lehman- Mckeeman, L.D., Johnson, D.R. and Caudill, D. (1997) Induction and inhibition of mouse cytochrome P-450 2b enzymes by musk xylene, Toxicol. Appl. Pharmacol., 142, 169-177.

Luckenbach, T. and Epel, D. (2005) Nitromusk and polycyclic musk compounds as long-term inhibitors of cellular xenobiotic defense systems mediated by multi-drug transporters, Environ. Health Perspect., 113, 17-24.

Paasivirta, J., Sinkkonen, S., RAntalanien, A.-L., Broman, D. and Zebühr, Y. (2002) Temperature dependent properties of environmentally important synthetic musks, Environ. Sci. Pollut. Res. Int., 9 , 345-355.

Peck, A.M. and Hornbuckle, K.C. (2004) Synthetic musk fragrances in Lake Michigan, Environ. Sci. Technol., 38, 367-372.

Peck, A.M. and Hornbuckle, K.C. (2006) Synthetic musk fragrances in urban and rural air of Iowa and the Great Lakes, Atmos. Environ., 40, 6101-6111.

Peters, R.J.B. (2003) Hazardous Chemicals in Consumer Products, TNO-MEP-Report.

Peters, R.J., Beeltje, H. and van Delft, R.J. (2008) Xeno-Estrogenic compounds in precipitation, J. Environ. Monit., 10, 760769.
Reguerio, J., Garcia-Jares, C., Llompart, M., Lamas, J.P. and Cala, R. (2009) Development of a method based on sorbent trapping followed by solid phase microextraction for the determination of synthetic musks in indoor air, J. Choromotogr. A, 1216, 2805-2815.

Ricking, M., Schwarzbauer, J., Hellou, J., Svenson, A. and Zitko, V.V. (2003) Polycyclic aromatic musk compounds in sewage treatment plant effluents of Canada and Sweden-First results, Mar. Pollut. Bull., 46, 410-417.

Rimkus, G.G. and Wolf, M. (1996) Polycyclic musk fragrances in human adipose tissue and human milk, Chemosphere, 33, 2033-2043.

Rimkus, G.G., Rimkus, B. and Wolf, M. (1994) Nitro musks in human adipose tissue and breast milk, Chemosphere, $\mathbf{2 8}$, 421-432.

Rimkus, G.G., Gatermann, R. and Hühnerfuss, H. (1999) Musk xylene and musk ketone amino metabolites in the aquatic environment, Toxicol. Lett., 111, 5-15.

Salvito, D. (2005) Correspondence: synthetic musk compounds and effects on human health, Environ. Health Perspect., 113, A802-A803.

SCCNFP (2004) Opinion of the scientific committee on cosmetic products and nonfood products intended for consumers, musk xylene and musk ketone, Report No: SCCNFP/0817/04.

Tas, J.W., Balk, F., Ford, R.A. and van de Plassche, E.J. (1997) Environmental risk assessment of musk ketone and musk xylene in the Netherlands in accordance with the EU-TGD, Chemosphere, 35, 2973-3002.

USEPA (1997) Exposure Factors Handbook. Washington, DC, Office of Research and Development National Center for Environmental Assessment, EPA/600/P-95/ $002 \mathrm{Fa}$.

USEPA (2007) Florisil Cleanup, Method 3620C, Revision 3.

Yamagishi, T., Miyazaki, T., Hori, S. and Kaneko, S. (1981) Identification of Musk Xylene and Musk Ketone in freshwater fish collected from Tama River, Tokyo, Bull. Environ. Contam. Toxicol., 26, 656662. 